\title{
Re-think the ex-ILVA landscape. Bagnoli's public park, Naples 2021
}

\author{
Iris Dupper \\ LATZ+Partner, Kranzberg/Munich, Germany \\ i.dupper@latzundpartner.de
}

\section{Tilman Latz}

LATZ+Partner, Kranzberg/Munich, Germany

t.latz@latzundpartner.de

\begin{abstract}
Since public space is usually associated with flexible open structures, this article looks into the transformation of the closed ex-ILVA grounds, as public green sphere, to underline emotional components in leftovers and urban policies, that add insights to the contemporary debate about environmental and social achievements of public spaces.

The re-thinking of contaminated post-industrial landscapes as participatory places is not only a change in process, quality and meaning, but also a microclimatic amelioration by reducing urban heat intensification, proving to have increasing effects on human health and well-being. Emotional compontents about community identity, saftey and history are examined.

How should a public urban park be designed by low initial and maintenance costs, supporting daily frequencies of citizens and health in mind and body, is the research question. More specific, how can contaminated sites be transfered into a healthy, sustainable and socially controlled public park, which idealy generates income, added value and increases life quality, respecting life expertancy, mortality rates and social well-being.
\end{abstract}

\section{Keywords}

Reclaiming public space, healthy microclimate and soil, dialectic, participatory places, identity and industrial heritage 


\section{Designing the research project.}

\section{Conceptual framework for research project describ-}

\section{ing how research questions are conceptualized}

The planning transformation of industrial facilities into new urban public space is preceded by their decommissioning. After years of standstill, the neglect of places, landscapes and regions, people emotionally no longer associate anything positive with what is left of the once prosperous plant. People do not feel comfortable, nor safe within these neglected spaces, which might not be usable or accessible by the public anymore. Industrial landscapes are per se subject to constant change. Competitiveness requires the will to change. If this will is lacking, decline is usually pre-programmed, which often comes along with the loss of intangible, ethical and aesthetical values. This can be shown by the example of the former Ilva iron and steel works in Bagnoli with successive processual phases of decline: shock, destruction, foreign domination, failure, and finally the attempt at reorientation through the launch of international competitions, such as the 2019-2021 international second phase competition by Invitalia.

We illustrate our research approach (official competition entry for the revitalisation of the Ilva landscape in Bagnoli) with focuses on anthroposophical, philosophical, social, ecological and sustainable components, in order to create qualities for every-day urban spaces of comfort and well-being, with dynamic relations to modes of living and urban planning of flexible uses, to adaptability in biodiversity and leisure.
The research planning process searches for intrinsic potentials benefiting society by means of innovative design and experiments, searching for participatory places connecting to Bagnoli's identity along the Caldera ridge of Posillipo.

\section{Research for planning transformation process. Theoretical foundation}

Following the assumption that there is a transactional relationship between people and place and that the experience of environment is influencing, what we want to do in it and how it serves our needs of the moment in context of memories and past experiences we focus on research topics, like 'social control in public park', 'health', 'affordability', 'sustainability' and 'uncontaminated ground achievable by vegetation'(Little, 2000; Ward Thompson, 2017). These topics were equally researched as essential planning elements in authors realised projects, like Landschaftspark Duisburg Nord, Germany (Latz, 2017) or Parco Dora - Spina 3, Torino, Italy.

After a joint analysis and data collection process of social, geological, archaeological, ecological economical aspects (Andriello et al., 1991; Haensler, 2003; laccarino, 2006 ; Palma et al., 2009; Corniello and Ducci, 2019), as well as the consultation of resources directIy on the Bagnoli site, different pre-conditions for the planning transformation process are clustered. 
Primary analyses look into the given situation, determined by geomorphology, contaminated soils and the current appearance and quality of the Canals Arenile di Sant' Antonio and Bianchettaro. Secondary analyses look into exisiting infrastructural systems and social studies, which are particular for the Naple's region, like adequate scales for building structures, that promote socially controllable neighbourhoods. Based on the outcome of these primary analyses, the positioning and typologies of new urban settlements along the site's fringes are focused, taking into account the outcome of the secondary social and economic analyses of the region. Specific topics are qualitatively and quantitatively researched into more detail, like public-private partnerships, the ex-Ilva relicts, adequate size and scale, types of sandy beaches, types of traditional sport activities (like canooing and watersports), levels and terracements, groundwater horizons, the experienceability of water (canals, ponds, sea), plant adaptability to differents conditions with saline and freshwater, applicability of phytoremediation for contaminated soils, archaeological and historical elements and predominant wind directions in relation to microclimate. Based on these results new infrastructural nodes, connections to public transport systems and corresponding parkings lots are synthesiszed.

The research focus is orientated on environmental quality in relation to the usablitiy of the 130 ha public park for people off all ages on a day-to-day basis.

\section{Conceptual framework of urban setting}

The peripheral nodes of the Bagnoli Mediterranean coast between the gulf of Naples, the Campi Flegrei and about $13 \mathrm{~km}$ of surrounding caldera levels, connect the western sub-urban to the urban fabric and finally to the mountains towards the volcano Vesuvius. Different categories of infrastructural systems are found dating from ancient roman times as coast- ing from Naples city centre as public metro line, local and regional connecting roads or autostrada lines. Public space is strongly related to accessibility and policies regarding the management of 'ground'. From the urban and social perspective, the ex Ilva steelworks in Bagnoli, as the former heart of Italian steel production, appears today as non-accessible and social 'void' within one of Italy's most densely populated urban sprawls covering an metropolitan area of over $1,000 \mathrm{~km}^{2}$ with a Bagnoli population of around 25.000 and an overall metropolitan population of 4 million inhabitants.

The ex Società Anonima Ilva with a capacity of eventually 2.3 million tonnes of steel with two blast furnaces were built by the end of the 1960s. Political conflicts stopped the construction of a hot rolling mill. From the 1970 s onwards, the plant operated at a loss, which ultimately led to its closure in the steel crisis 1991 and was hopelessly outclassed in the global competition. By 2005, parts of the structures were demolished. The attempt to redevelop the site in 2016 and to attract new companies was not successful. Since decades the area is suffering from the economic crisis, of removal and decay with around $18 \%$ high unemployment rates.

For these reasons the urban integration of the new park into the surroundings of Bagnoli, Coroglio and Cavalleggeri attempts to address itself and attract especially the young population. Central guiding principles need therefore to give a perspective for new jobs, coexistence, collaboration and for shared uses of new urban constructions on a fertile ground. A resource-friendly development approach links public accessibility with the existing green along the Caldera edge.

\section{Approach for transformation process}

As a concept we link "environmental attributes with people's perceptions of them in relation to their own, idiosyncratic desired and necessary activities" (Ward Thompson, 2017, p. 235). 


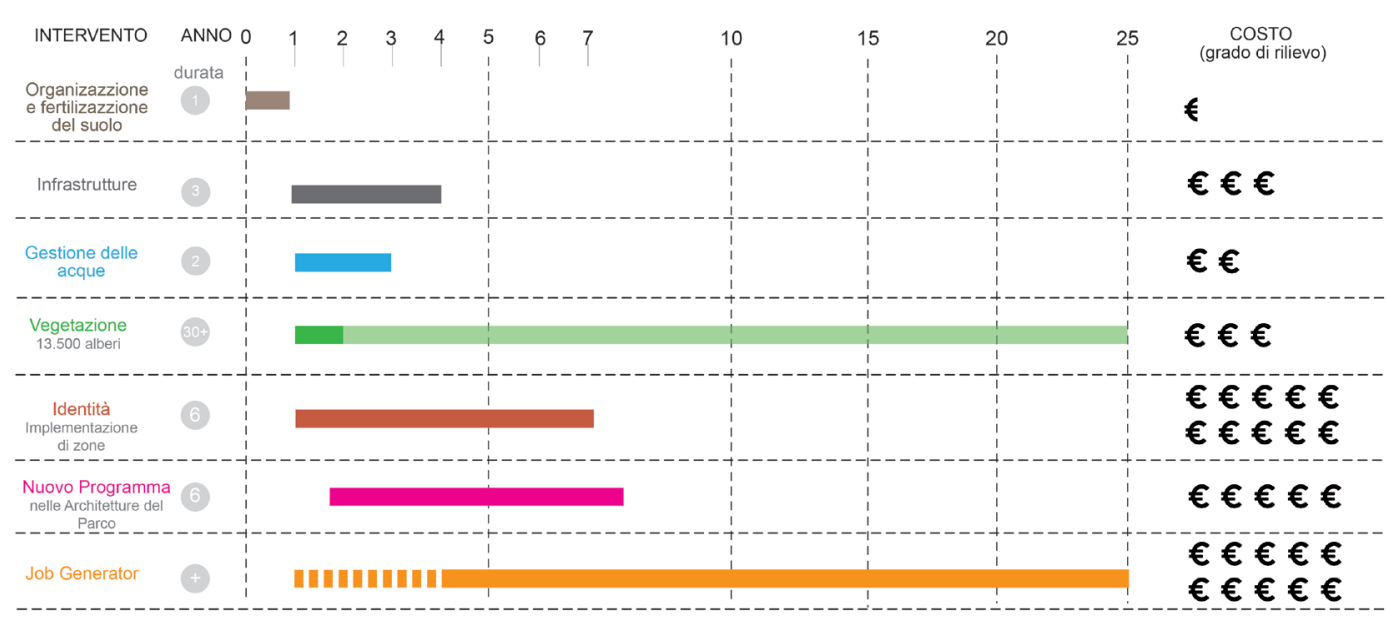

Tab.1 - Ratio between economic input and effect in timeline within 25 years.

This approach is confirmed by experiences the authors made along the planning process of the project, e.g., Masterplan Spreepark Berlin, in which peoples' perceptions were equally linked to activities.

Places of remembrance are especially related to communities' identity and should therefore be re-activated and become alive. Bagnoli's future public places are multi-coded and inclusive, due to different actors and uses, without losing historic attributes, nor identity (Bracken, 2014). The aspiration to create an innovative landscape goes along with a framework of conditions for the initiated transformation process. Cultural building relicts and cultural forms of expressive, immaterial values, like emotional components of remembrance, find new meanings of public places related to ground. The recycling of structural elements, as well as the amelioration of soils quality by re-nature strategies, secures cultural heritage, transforms it experienceable for citizens into a sustainable park of the $21^{\text {st }}$ century. Interactions between users, neighbourhood and visitors are the basis of stimulating new innovative experiences. The redevelopment of the area improves public accessibility for the neighbourhood, as an important part of local communication and shaping of identity. Via the platform 'cultural landscape' a personal and emotional dialog with the history of the site is encouraged.

\section{Research design}

Our approach takes into grant the comparative importance of different environmental elements (Ward Thompson, 2017). The challenge is to find a sensitive processual planning approach over two decades for the transition from a 130 ha post-industrial wasteland into a public park between preservation and transformation, which protects the character of the site and marks it at the same time as public space.

The new park is characterized by short and long-distance pathways with a focus on quality, aesthetics of experience ability, which responds to the everyday needs of local residents, from children to elderly people. The use of former industrial routes creates participative spaces for multifunctional diversity applying e.g., circular economy ideas, the recycling and re-use of building elements, set in a new context of meaning and perception. Vegetation helps to create a new landscape of high biodiversity, which, in combination with the existing habitats along the Caldera, becomes a critical vegetative mass for nature conservation (Tab. 1).

The dialogue between citizens, investors, stakeholders and knowledge holders (Ostrom, 2007) is facilitated by the implementation of a project 


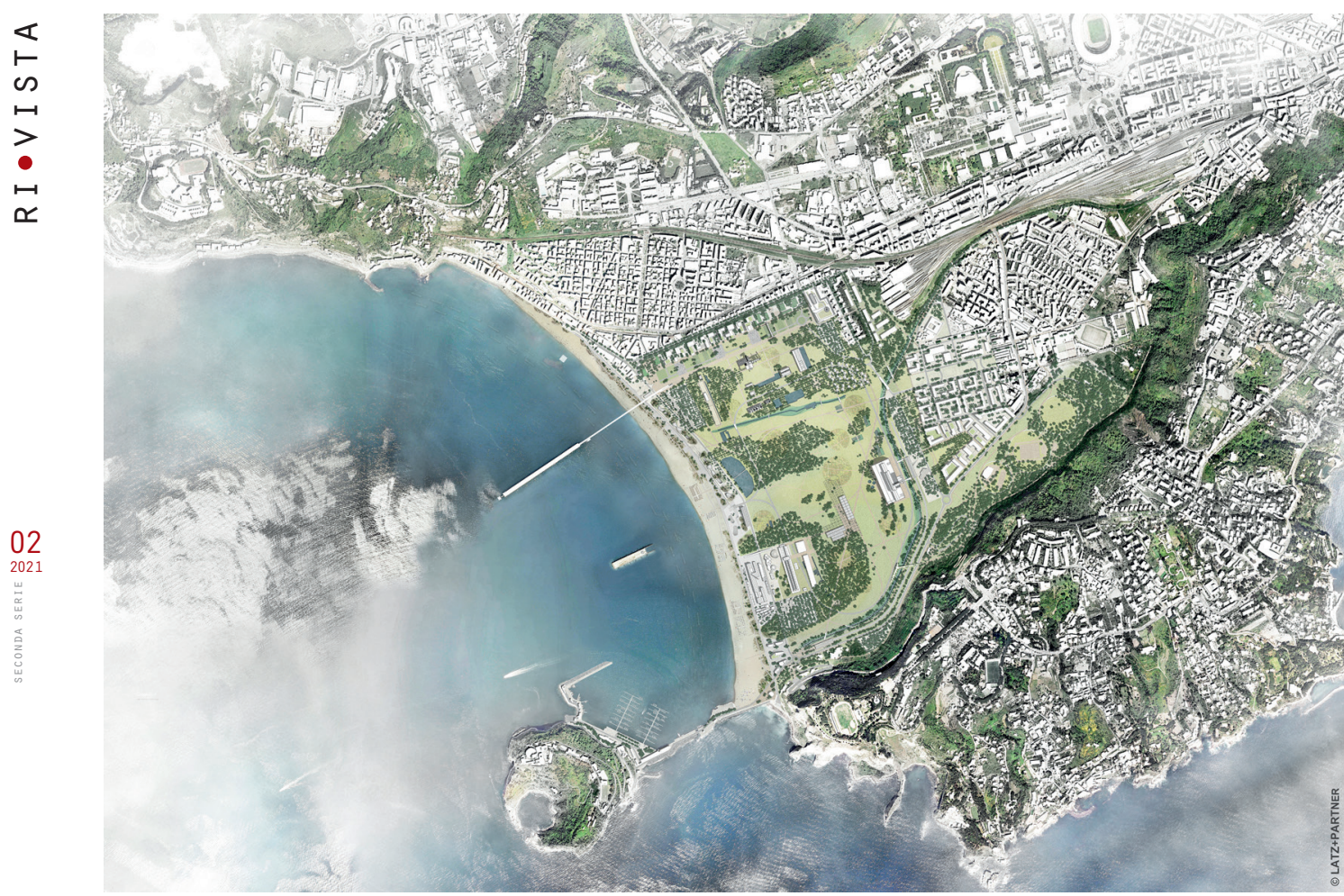

Fig. 1 - New urban neighbourhoods around the Bagnoli Park fringes.

communication plan with a meta-organiser (public-private partnership). Together they manage to forward the project and activate a territorial management group, that guarantees feasibility, participatory management and sustainability. Most financial input has to be provided in the initial 7 years, whilst the positive effects, like generated jobs or arising woodlands, appear after the initial 7-year span.

By participation in park work, citizens and groups, like, Friends of the Park' grow together, from the exciting beginnings to the satisfactory maturity. The project gives new meanings and interpretations to urban space by innovation, creativity and landscape design and a responsible usability of land, in order to stimulate impulses for new behaviours in public space. Human-scale surroundings and affordable neighbourhoods with sportsgrounds are made accessible by foot and cycle path connections along ecological corridors with high biodiversity.
The Park is orientated on pedestrians' and cyclers' perceptions and distances, whilst cars are generally parked in parking garages related to building units. Cultural events reinterpret and celebrate the former industrial spaces as 'new flames in newly converted halls.' Public spaces are chained along former ,industrial paths, while newly planted areas define spaces and boundaries within the extensive park space, that convey a sense of coexistence, inclusion and immersion as a feeling of freedom and rootedness at the same time.

The environmental quality of the new neighbourhoods adjacent to the park is created by the increase in biodiversity, the introduction of an innovative water system, good connectivity and security within the park. Changes in soil, light, planting density and vegetation species influence the occupation of the site and produce side-effects on the microclimate. As an educational park near the sea, it offers children, 


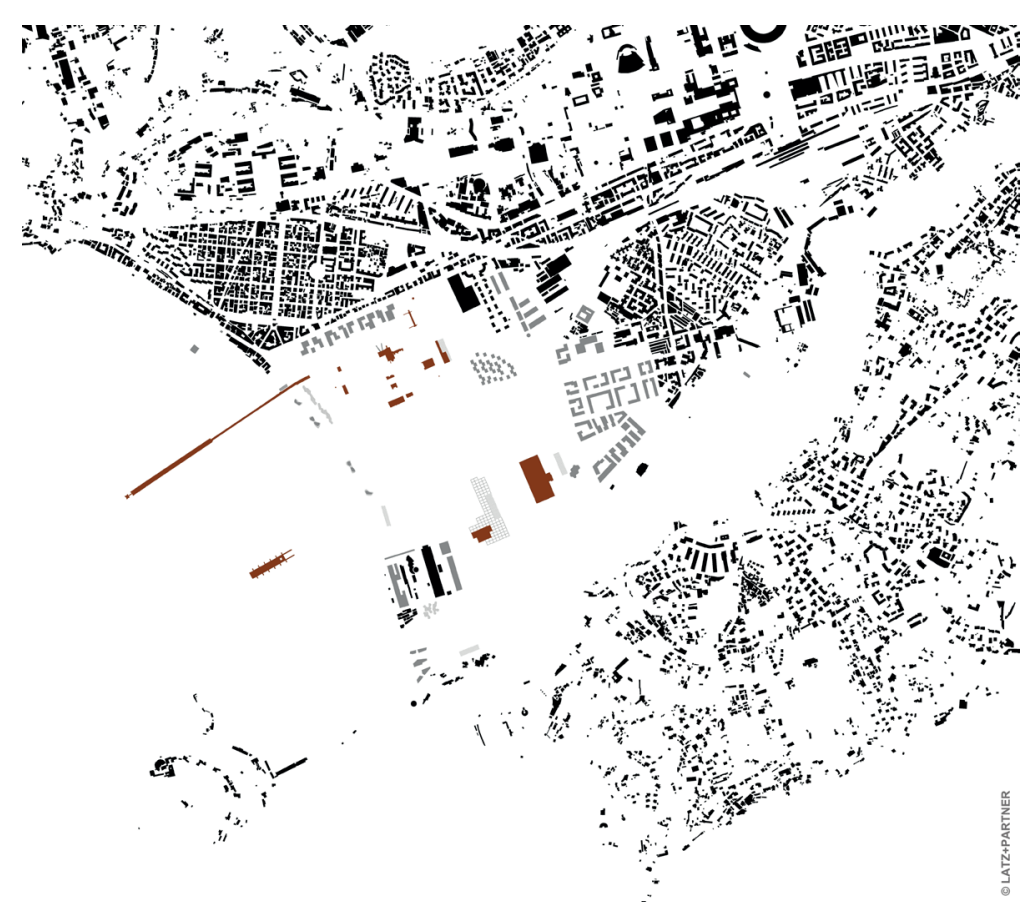

Fig. 2 - Urban fringes (grey); re-used elements (brown).

young people, citizens and Naples visitors interesting experiences along didactic facts about existing and new vegetation structures, as a large botanical teaching garden and think-tank, where ideas, like those of the New Eu Changes in soil, light, planting density and vegetation species influence the occupation of the site and produce side-effects on the microclimate. European Bauhaus, can be applied in continuing the story of a historic place along historical heritage in new perspectives (Fig. 1 and 2).

\section{Designing the research project}

\section{Space - Corridors of Life - Cultural Park}

As an urban offer to the citizens, new small-scale building volumes are created along the park's edges offering car parks in the basements. As new locations of cultural or economic nature, they over the park and the Mediterranean Sea. A processual development of the structures in the area favours a social and functional mix, promoting inclusion and security. Architecturally and urbanistically, this translates into high-quality, mixed housing types of small units and structures for different uses, such as residential, commercial or tourism. On land and sea functional spaces for sports facilities and cultural projects are created in relation with the new park, as cultural links between geomorphological, fluvial, territorial, historical and archaeological landmarks, such as the former Strada Regia as a straight connection from Naples to the coastal road to Pozzuoli or the Collina Santa Teresa (Fig. 3). As a man-made water system in the landscape, the Canale Arenile di Sant' Antonio and Canale Bianchettaro are reconceived as an experienceable waterline and eco corridor.

Since about 10,000 people visit yearly the Grotta di Seiano, as access to the Posilipo - Gaiola archaeological park, innovative parking solutions are re- 


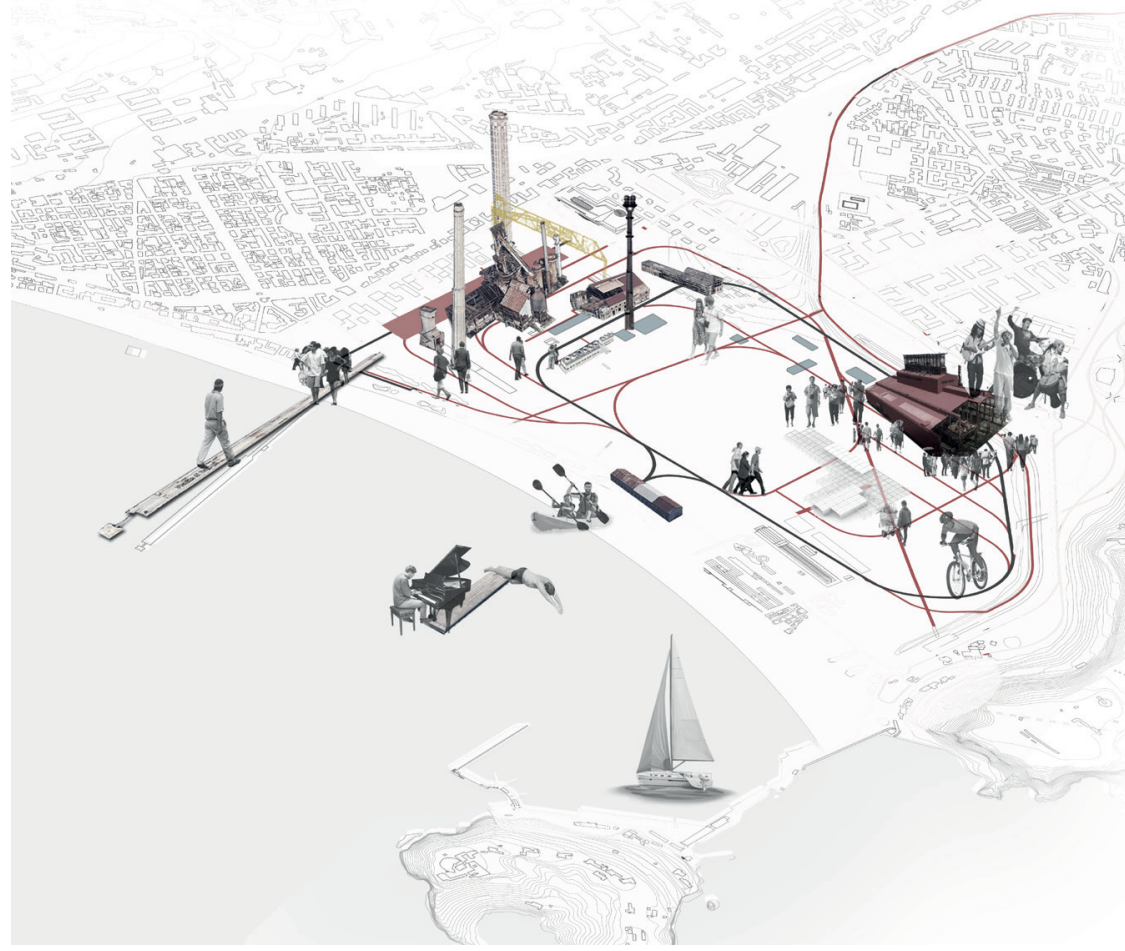

Fig. 3 - Walking like the former trains.

quired, which can shade and generates solar power simultaneously, in order to guarantee a sustainable parking management on several spots in the park. The red Acciaieria hall is converted into a vibrant cultural centre and think tank for start-ups, crowned by a viewing platform, with the largest central car park modules, connected to public transport.

Time - Walking like the trains of the former ILVA iron and steel works - industrial park

The Park aims to bring people and elements together through a hierarchy of paths, their materiality and memory.

Remains of the former Ilva centre are secured as cultural heritage of the industrial archaeological site and connected by a modern park path system for pedestrians, cyclists and sports enthusiasts. It ramifications; the continuity of the historical linear industrial routes enables a systematic experience on new paths.

Historical elements in the sequence of former production lines provide a generous, elegant and sustainable structure for the development of the new park. Its "mountains" are the steelworks and the blast furnace, spectacular "monsters" of steel, cement and bricks up to 70 metres high. Its "cliffs" are the former piers, - its "valley" is the Arenile di Sant'Antonio and its gorge the Canale Bianchettaro. It bows to the dramatic topography of the Campi Flegrei, the caldera of Posillipo, the hills of Agnano and the island of Nisida. It is the new stage where urban society meets. The new architecture connects to the historic structures, brings new life to the old halls reinterpreted architecturally and extends the lines of sight as 'mise-enscene' from accessible vantage points. 

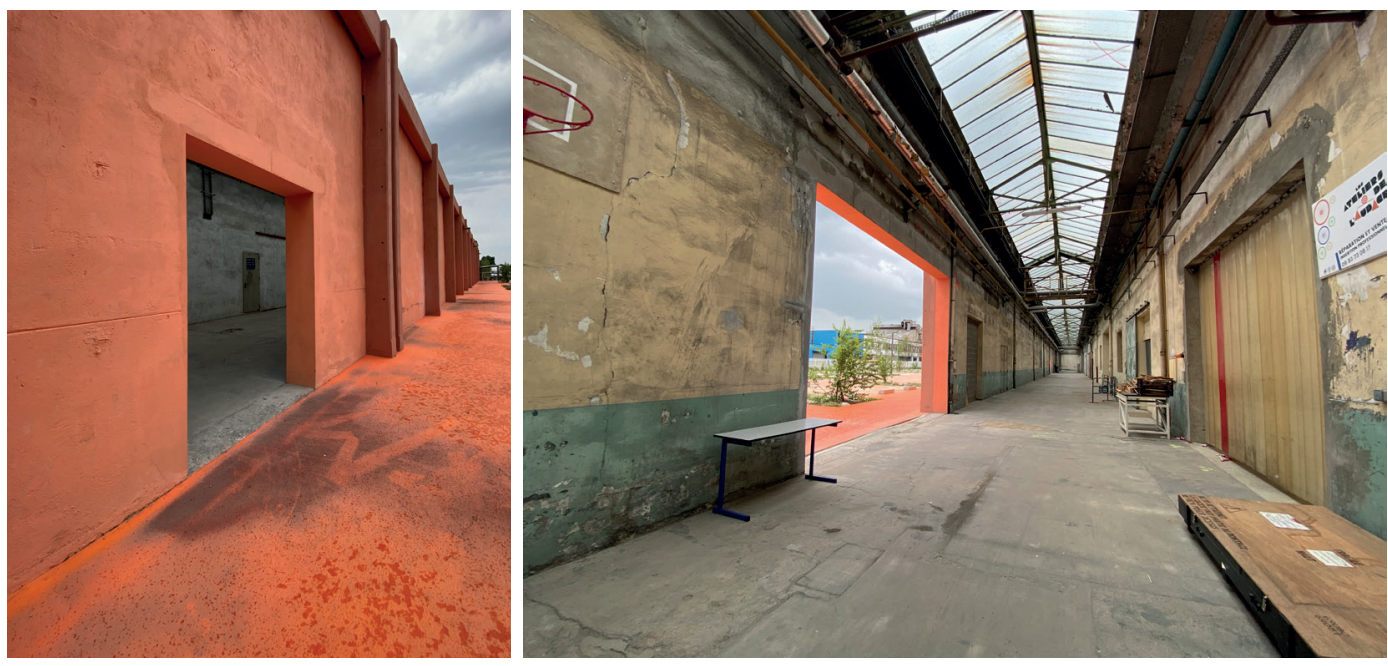

Fig. 4 and Fig. 5 - Corridors of life - Reference for re-use of building structures in new context; Sheds /TASE Lyon, France (design by Latz and Partners realized in 2021)

Old pavilion buildings are simply, carefully and cost-effectively restored (Fig. 4, 5). They preserve their nature and history in the interior and exterior spaces. Rentable for civic festivals and community celebrations, they are the new venues for culture, music, art and theatre, for gatherings, presentations and sports, as parts of Naples' public space.

The central part of the park, especially the steel mill corridor, offers multi-functional spaces for future uses, such as outdoor concerts, picnics and sports.

Forest-like tree structures connect the sea with the city, direct fresh air to surrounding neighbourhoods and allow various changes of perspective. In order to have a cooling effect on the microclimate and create spatial configurations for flexible activities, fresh air corridors are directed by ecological habitats in extension of the pre-dominate wind direction (Fig. 6.7).
This new morphology of the future park also changes the way water is collected and used, by retaining it in a decentralised way, collecting it, storing it in re-used basements of building elements and making it experienceable. The canaled water systems are upgraded as a new landscape with semi-aquatic habitats for flora and fauna and converted into an experimental field for environmental technology. The hydraulic barrier will be rebuilt as water areas and stopovers for water birds. It is here where citizens promenade to experience cloud reflections, as a multifaceted park element. Water for irrigation can now be offered everywhere in the park depending on demand for vegetation irrigation. Next to the new urban front of Bagnoli, urban spaces and an archaeological landscape are created as meeting points for participation of the local community. 


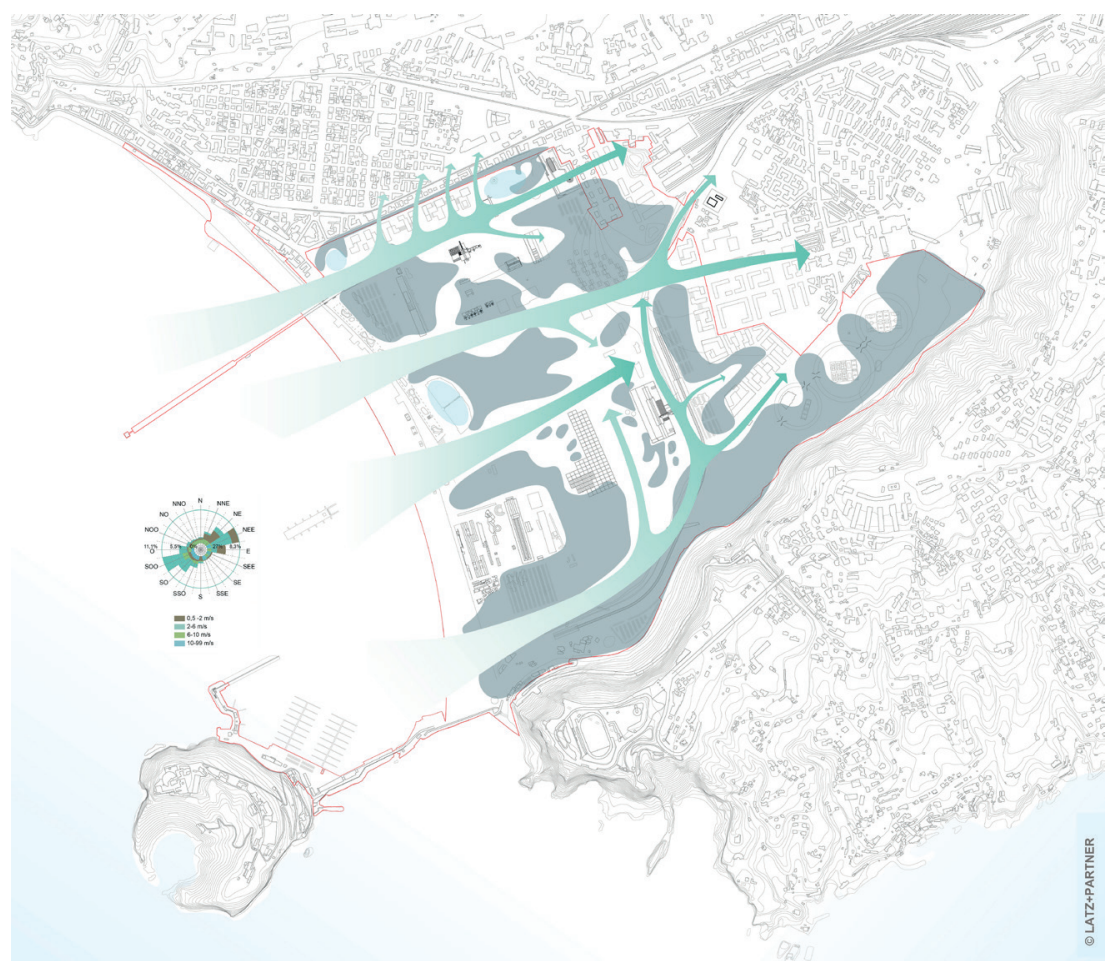

Fig.6 - Enhancement of microclimate.

From south to north, vegetative park elements gradually transform from fluid to defined configurations. In the former raw materials storage area of the factory, sequences of spaces for different activities are created out of the raw materials, such as playgrounds and archaeological areas. Along the main industrial route water reservoirs, gymnasiums, cinemas, art workshops, residences for artists, cultural associations, meeting spaces for public and private events are chained in the ruins. Organisations, such as 'Friends of the Park' move into the old walls, offering guided bike tours through the park. Squares are designed with tangible materials that remind us of former uses. Oversized, urban pergolas covered in vines provide meeting places between the park gate and the new buildings. Home-grown fruit in the gardens of the districts are symbols and signboard of the new fertile soil.
The Padiglioni Morgan structures are surrounded by special gardens as a greenhouse and butterfly house, where climbing roses cling to the old steel supports, as visitor's magnet.

A $2.4 \mathrm{~km}$ long promenade defines the new Bagnoli coastline as a beach area framed by dunes, connecting to the park. Architectural modules pop out of the dunes and offer retail space for gastronomy, local products and arts and crafts (Fig. 8). The coastal strip Spiaggia di Coroglio now offers a continuous connection between sea and inner Bagnoli Park along the caldera edge.

The former Ilva archive building is architecturally reinterpreted as a museum, reshaped with a new roof and accompanied by a skate park, while the pier remains as place to promenade above the sea. The former central pier is largely deconstructed and used as a bathing platform and canoe harbour. 


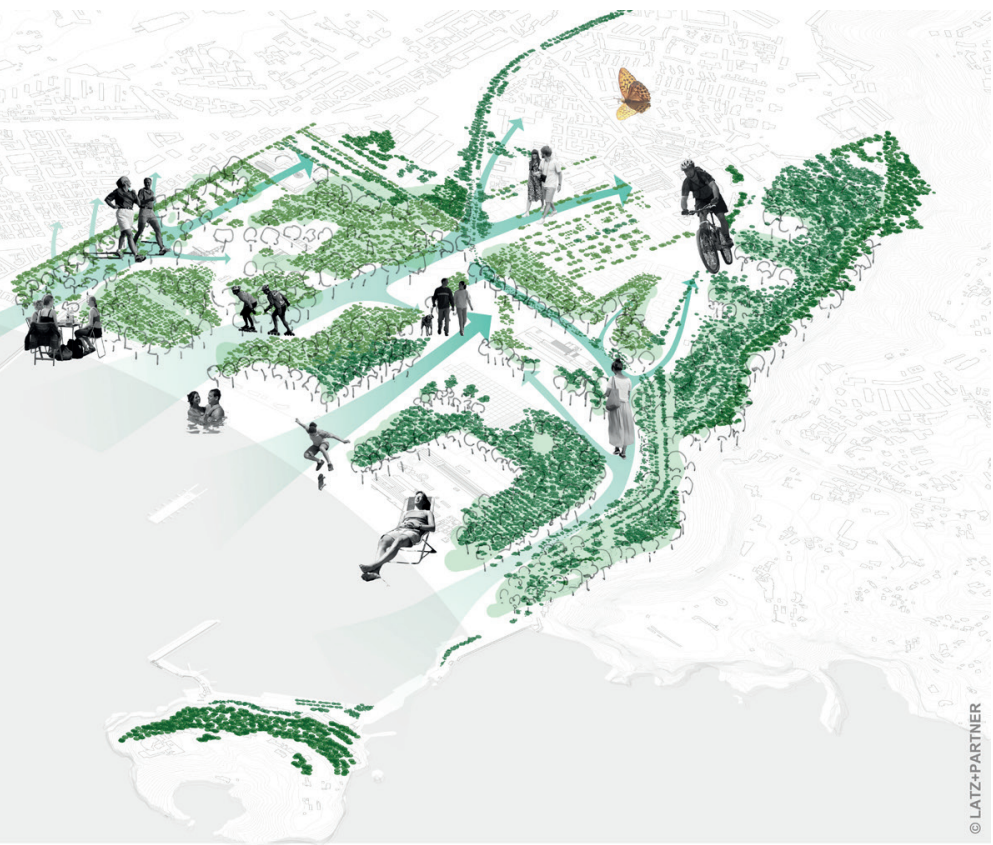

Fig. 7 - Vegetation enforcing cooling winds.

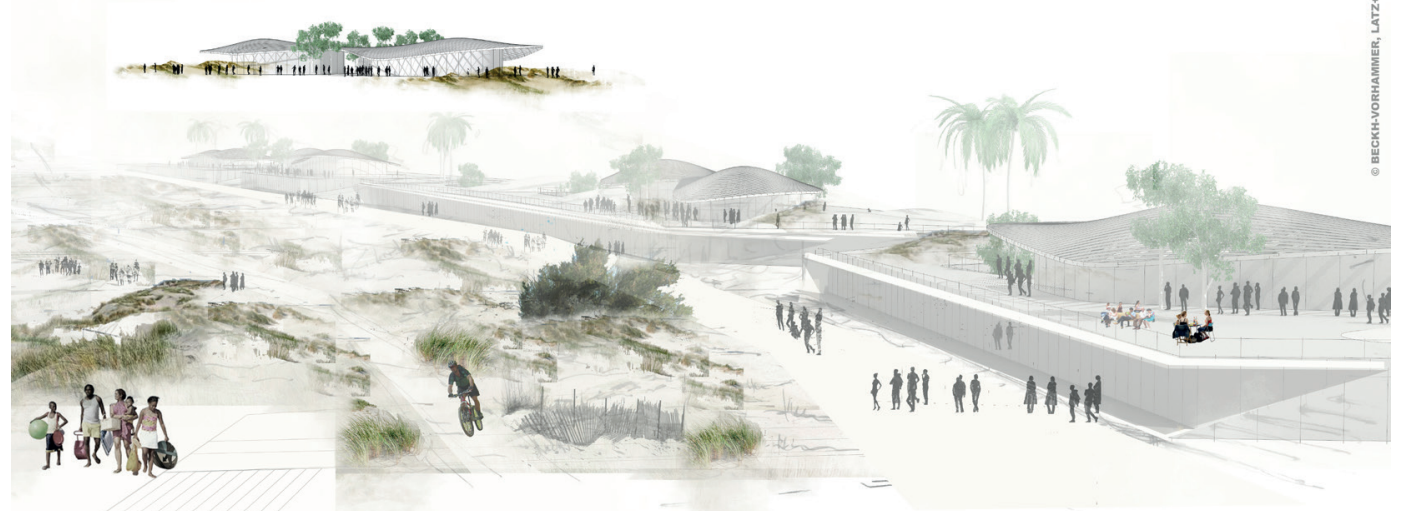

Fig. 8 - Architectural modules in between beach and dunes. 
Major parts of the currently inaccessible and partially contaminated site are overwritten by a new formative layer of public open space. This new landscape can be considered as critical mass for nature conservation and biodiversity in continuation with the existing habitats and offers equally a cultural landscape, which conserves elements of industrial monuments and remembrance.

Biodiversity depends on a successful soil colonisation process, which is a crucial quality of this new park with a slow, processual development of more than 100 ha of meadows, maquis and hedges, interspersed with linear tree plantations, orchards and woodland areas. The vegetation colonisation process can develop over a long period of time, since space is given to it in form of semi-transparent stretched 'canvases', which protect these inaccessible zones, offering available surfaces for temporary art exhibitions to engage in artistic dialogue.

Pioneer and scientific experimental fields are created to improve the soil quality of contaminated industrial soils (Sacchi et al., 2020) in the initial 5 years.

Some of them are reclaimed with phytoremediation species, such as legume seeds and appear as pioneer fields of phytoremediation (Pivetz 2001; Dechema, 2013; Kappler, 2013; Lessandro et al., saving finances and ground. After five years, promising qualities should already be achieved, so that after the Madh with green manure, umbrella pines (Pinus pinea) and isolated holm oaks (Ouercus ilex) can then be sown by hand. At the same time the city is provided with a unique nature. It is a landscape conservation area without being declared as such. Colourful plants and hedges of Mediterranean perennials, Crassulaceae and evergreen rosemary, Juniperus spp and occasional Opuntias arise behind the canvases in the next two decades.

The final goal of the phytoremediation plots is to establish new, large-scale forests as a man-initiated, natural process that can colonise a major part of the site over a period of 20 years. For this purpose, rectangles of $100 \mathrm{~m}$ per $10 \mathrm{~m}$ are traced, most of the fresh soil is sown and only a few large trees are planted with root balls, for the sake of sustainability. Umbrella pines and isolated holm oaks dominate and are accompanied by many smaller accentuated plants (Tab. 2).

The tree species interpret the topography of the park: at first, coniferous and pioneer tree species dominate, before cork oaks, pines, tamarisk and cypress manage to established themselves on the hills and slopes after a few years, while poplars, willows and alders are permanently established in wet plains. As sunburn during summer months, potential crisis points for seedlings is wind drought. Competition with weeds is resolved by providing vegetative shading and wind screening, as well as high seedling density. Trees appear in two different spatial configuration mods: loosely arranged trees emphasise the dramatic topography along the caldera, extend to the trees of the sports park and accommodate the new transport infrastructure; smaller, more intimate park spaces are created, where the experience of flora and fauna is paramount. Trees arranged in grids appear as landscape architectural structures connecting to the rationality of the industrial past. In the northern area, they allow deep 


\section{YEAR 1}

Populus and willow shade and structure the soil

Leguminous plants revitalise the barren soil

\begin{tabular}{|l|l|}
\hline willow & leguminous \\
\hline leguminous & poplar \\
\hline leguminous & leguminous \\
\hline willow & willow \\
\hline leguminous & leguminous \\
\hline poplar & poplar \\
\hline leguminous & leguminous \\
\hline
\end{tabular}

\section{YEAR 5}

Populus and willows are cut down, sown pine and holm oak plots are protected by shade of 5 years pines and holm oaks, that are now more than $1 \mathrm{~m}$

\begin{tabular}{|l|l|}
\hline pine & holmoak \\
\hline pine & holmoak \\
\hline holm oak & pine \\
\hline holm oak & pine \\
\hline pine & holm oak \\
\hline holm oak & holmoak \\
\hline holm oak & pine \\
\hline pine & pine \\
\hline pine & holm oak \\
\hline
\end{tabular}

\section{YEAR 3}

Populus and willows, now $4 \mathrm{~m}$, shade and protection for seedlings

\begin{tabular}{|l|l|}
\hline poplar II & holm oak \\
\hline pine & willow II \\
\hline willow II & pine \\
\hline holm oak & poplar II \\
\hline poplar II & holm oak \\
\hline pine & willow II \\
\hline willow II & pine \\
\hline holm oak & poplar II \\
\hline poplar II & holm oak \\
\hline pine & willow II \\
\hline
\end{tabular}

\section{YEAR 20}

Pines and holm oaks compete with each other, the micro-habitat determins the condition for the dominance for either one in different areas

\begin{tabular}{|l|l|}
\hline pine & pine \\
\hline pine & pine \\
\hline pine & pine \\
\hline pine & holmoak \\
\hline pine & holm oak \\
\hline holm oak & pine \\
\hline holm oak & pine \\
\hline pine & pine \\
\hline pine & holmoak \\
\hline
\end{tabular}

Tab.2 - Soil regeneration species mix in plots by $100 \mathrm{~m} \times 10 \mathrm{~m}$ for period 1 -20 years. 
insight into the car parks, communication over long distances, flexible use and social control options (Jacobs, 1961).

In two decades, an established and usable pine forest with occasional holm oaks emerges, in which climax community species can spontaneously establish themselves, introduced both by wind and by animals. A positive effect is that all selected species are adapted to the situation by forming taproots, are very hardy and resistant to high salinity in the air. Half of the currently inaccessible areas will be designed as free-growing and widely usable 'garrigue' of locally adapted species, the other half as meadows and parterres for more intensive uses. Carrigue extends from the Parco dello Sport and the slopes of Posillipo towards the plain. Visitors enjoy their protection, the typical smells and colours and the special fauna. Meadows, on the other hand, are shaped by mowing and thus respond flexibly to changing user behaviour or the requirements of major events. The water concept is rethought, in order to enable vital greenery and maintain it in long term. Surface drainage, water collection and water reuse are considered separately. The forest edges are modified over the years to incorporate new things and enhance spatial effects. The processual development of vegetation and the amelioration of the soil mean 234 long years of change.
However, this opens opportunities for a conscious experience of natural processes and the promotion of social responsibility on common ground. An additional ecological corridor is created around the wetlands of the Canale Arenile di Sant' Antonio and Canale Bianchettaro, connecting to the island of Nisida and the marine park.

\section{Reporting on knowledge gain}

Rethinking public space with its unique intangible design, considerable transformations can be achieved by freeing of the abandoned ex_Ilva site, re-using it's abandoned industrial infrastructure and ameliorating its contaminated soils. This opened the scene to a transformation process into a beautiful public park with unique, world class open spaces. Thanks to this process the green share within the city of Naples can be increased. This greening project could be undertaken with co-funding of the City of Naples, the Region Campania, the Italian State and EU-funds, since new European Bauhaus goals are focused.

The transformation of this industrial wasteland into a public park and economically advantageous environment, attracts younger generations, generates new jobs and proves comparable potentials for other post-industrial sites or seaside. To achieve this, strategies have to be put in place, that stim- 
ulate common action, take advantage of driving forces, the genius loci and its intrinsic potentials. A well-founded analysis process and planning approach can enhance the quality of life on site in terms of health, safety, culture, added value and ecology (Hartig et al., 2014).

Contaminated soils are made accessible over time and assist to adapt to climate change by the use of phytoremediation and by the illustrated vegetation strategies, offering green, sustainable solutions. In order to find out more about, which vegetation species are most suitable for the Bagnoli soils, it would have helped to implement a research prototype plot on site, over a time span of at least 5 years with measurable parameters.

The developed «Eigenart » is an essential criterion of scenic beauty and spatial expression of collective goals, merges here into a sum of participatory places that touch on issues, like identity, rootedness and social ties.

As stated earlier, this research example points with evidence to ways, that landscape architects and their teams have a lot to offer to the current challenges, especially in collaboration within a larger team of professions, as it was the case for this research project.

\section{Notes}

The authors of the present article represent the relevant scientific team and official participant of international ideas competition for the redesign of the new landscape of Bagnoli, Naples 2019-2021

Official participant of international ideas competition for the redesign of the new landscape of Bagnoli, Naples 2019-2021.

CONCORSO INTERNAZIONALE DI IDEE PER IL DISEGNO DEL NUOVO PAESAGGIO DI BAGNOLI - COMPRESA LA DEFINIZIONE PLANIVOLUMETRICA DEL NUOVO EDIFICATO DI CUI AL PROGRAMMA DI RISANAMENTO AMBIENTALE E RIGENERAZIONE URBANA (PRARU)

Client: INVITALIA Rome

Surface: 247 Hectar

Team under the lead of LATZ + PARTNER (Landscape architecture and urban planning): Tilman Latz, Iris Dupper,

Sonja Hlawna, Flavia Laureti, Francesca Giantin, Sophie Klein, Han Mai, Ana Wiggin Rodriguez

Project partners in Munich, Neaples und Turin: beckh vorhammer - Structural Computational Design; IdroGeo Srl di Vico Equense (NA); Agr. Dario Grua, (TO); For. Savino Mastrullo, (NA) ; Prof.ssa Anna Maria Zaccaria, (NA); Dr. Riccardo Staffa, (NA) ; Prof. PhD Marco Giglio, (NA) ; Dr. Cinzia Verde, (NA). 


\section{Author Contributions}

Iris Dupper, Tilman Latz, Matthias Beckh, Simon Vorhammer, Biagio Palma, Dario Grua, Savino Mastrullo, Anna Maria Zaccaria, Riccardo Staffa, Marco Giglio, Cinzia Verde. The study was researched and designed by I.D. and T.L., and together with M.B., S.V., B.P., D.G. conceived the project scenarios in terms of sustainability, heritage conservation and climate-based solutions:

The vegetation and phytoremediation research and preliminary agro-forestry studies were done by I.D. D.G., S.M.

The geological and geotechnical research was done by B.P. The industrial heritage conservation scenarios were done by T.L.

The water management research and scenarios were done by T.L., B.P.

The economic studies and management scenarios research were done by I.D., R.S.

The social and cultural research was done by A.-M. Z., C.V. The social scenarios for urban development were done T.L., I.D., A.-M. Z.

The marine coastal studies were done by C.V., marine coastal scenarios were developed by T.L.

The archaeological studies were done by M.G.

I.D. and T.L. wrote the paper, I.D. reviewed and curated it.

\section{Bibliography}

Andriello V. Attilio B., Lepore D. 1991, Il luogo e la fabbrica. L'impianto siderurgico di Bagnoli e l'esapansione occidentale di Napoli. Graphotronic Ed., Napoli.

Baytar, O., Ceyhan, A. A., \& Şahin, Ö. 2021, Production of activated carbon from Elaeagnus angustifolia seeds using H3PO4 activator and methylene blue and malachite green adsorption, «International Journal of Phytoremediation», 23(7), 693-703.

Bracken, J. 2014, The Important Difference between Change and Transition, http://quality-texas. org/ wp-content/uploads/2014/11/The-Important-Difference-between-Change-and-Transition. pdf, checked on, 4(7), 2016.

Corniello A., Ducci D. 2019, Hydrogeochemical characterization of the urban coastal aquifers of Napoli (southern Italy): an overview, « Acque Sotterranee », Italian Journal of Groundwater, 8(1).

DECHEMA. 2013, Gesellschaft für Chemische Technik und Biotechnologie e.V. (Hg.): Geobiotechnologie Stand und Perspektiven, Statuspapier, Frankfurt a. M. https://www.biooekonomiebw.debiotech.dechema.de/ biotech_media/Downloads/PositionsundStatuspapiere/ Statuspapier+Ceobiotechnologie.pdf .

Haensler J. 2003, Phytoremediation schwermetallbelasteter Boeden durch einjaehrige Pflanzen in Einzel- und Mischkultur (Doctoral dissertation), Heinrich-Heine-Univ. Duesseldorf, Wuppertal.

Hartig T., Mitchell R., De Vries S., \& Frumkin H. 2014, Nature and health, "Annual review of public health», 35, 207-228. 
Hussain Z., Rasheed F., Tanvir M. A., Zafar Z., Rafay M., Mohsin M., ... \& Ruffner C. 2021, Increased antioxidative enzyme activity mediates the phytoaccumulation potential of Pb in four agroforestry tree species: a case study under municipal and industrial wastewater irrigation, «International Journal of Phytoremediation », 23(7), 704-714. https://doi.org/10.1080/15226514.2020.1849016

Iaccarino, L. 2006, La rigenerazione. Bagnoli: politiche pubbliche e societacivile nella napoli postindustriale, Modern Italy, 11(2), 227-245.ISPRA-Istituto Superiore per la Protezione e la Ricerca ambientale-servizio mareografico-rete mareografica nazionale 2014, Rete Mareografica Nazionale, Napoli, https://www.mareografico.it/

Latz, P. 2017. Rost Red - The Landscape Park Duisburg-Nord; Hirmer Munich.

Little, B.R. 2000. Persons, contexts, and personal projects: Assumptive themes of a methodological transactionalism; in Wappner, S., Demick, J., Yamamoto, T. and Minami, H. (Ed.) Theoretical Perspectives in Environmental behaviour Research : Underlying Assumptions, Research Problems, and Methodologies, Plenum, New York, p.79-88.

Jacobs J. 1961, The Death and Life of Great American Cities, Random House Inc., New York.

Kappler A. 2013, Universitaet Tuebingen.leh.BioRegio STERN. (c) BIOPRO Baden-Württemberg GmbH. https://www.biooekonomie-bw.de/fachbeitrag/aktuell/ boeden-biologisch-sanieren-phytoremediation-mit-unterstuetzung-von-bakterien

Ostrom E. 2007, Collective action and local development processes, «Sociologica», 1(3), 0-0.

Palma B, Calcaterra D. \& Parise M. 2009, Modelli geologici e meccanismi di innesco di frane da scorrimento-colata rapida nei depositi vulcanoclastici della Campania, « GEAM », 126. 21-48.
Pivetz B. E. 2001, Phytoremediation of contaminated soil and ground water at hazardous waste site, US Environmental Protection Agency, Office of Research and Development, Office of Solid Waste and Emergency Response.

Sacchi M., Matano F., Molisso F., Passaro S., Caccavale M., Di Martino G., ... \& Vallefuoco M. 2020, Geological framework of the Bagnoli-Coroglio coastal zone and continental shelf, Pozzuoli (Napoli) Bay, "Chemistry and Ecology», 36(6), 529-549.

Ward Thompson, C. 2017, Landscape and health, in Van den Brink et al., 2017 (Ed.), Research in Landscape Architecture, methods and methodologies, Routledge, Londo n and New York, p. 235-262.

\section{Websites}

https://www.biooekonomie-bw.de/fachbeitrag/dossier/ mikrobielles-rohstoffrecycling/[Accessed 7 July 2020]. https://land8.com/5-best-plants-for-phytoremediation/[Accessed 7 July 2020].

https://www.umwelteinsatz.ch/[Accessed 7 July 2020]. https://urbact.eu/naples/[Accessed 7 July 2020].

https://www.researchgate.net/figure/Rainfall-andtemperature-chart-of-the-Naples-Hydrographic-Servicefor-the-period_fig3_258769425[Accessed 7 July 2020].

https://www.weather2visit.com/europe/italy/napoli.htm[Accessed 7 July 2020].

https://transitmap.net/official-rapid-transit-naples-2019/[Accessed 7 July 2020].

https://www.orangesmile.com/common/img_metro_ maps/naples-map-metro-2.png

https://europa.eu/new-european-bauhaus/index_de[Accessed 7 July 2020].

https://ugeo.urbistat.com/AdminStat/en/it/demografia/popolazione/napoli/63/3[Accessed 7 July 2020]. 